\title{
Anatomical Expertise and the Hermaphroditic Body
}

\author{
Palmira Fontes da Costa*
}

In his influential work, A social history of truth, Steven Shapin (1995) has argued for the central role of social status in the assessment of experimental knowledge. In his view, in seventeenth-century England, gentlemen were considered the right kind of persons to trust because of their freedom of action, codes of virtue and honour. These characteristics ensured credibility and, hence, compelled assent. However, Shapin does not put sufficient emphasis on the relevance of the testifier's competence in the validation of knowledge. When and in which circumstances did expertise become more important than social status in the accreditation of natural knowledge?

It is not within the field of experimental culture but of medical practice and the making of medical knowledge that, in a more recent work, Shapin (2003) has argued for the importance of expertise. His study is concerned with the early eighteenth-century success of the physician George Cheyne. Shapin distinguishes between two kinds of expertise that were relevant for Cheyne's achievements and reputation, prudential expertise and ontological expertise. The nature of prudential expertise is that it need not pretend to flow from a knowledge of underlying processes that are considered different from, or superior in kind, to lay knowledge. What is relevant for the categorization of this kind of expertise is that it is based on judgment that is informed by accumulated experience. In opposition, ontological expertise claims its authority from the possession of special knowledge about the underlying or hidden structures of the world or of the domain in question. Therefore, such knowledge is different in kind from that held by lay actors or by prudential experts in the same domain. As Shapin remarks, "ontological experts alone penetrate behind appearances to hidden realities" (293). Anatomical expertise is not examined in Shapin's study but it can be considered that both prudential and ontological expertise are relevant in the establishment of this type of competence. However, ontological expertise is clearly more crucial since it grants anatomical experts exclusive authority in the interpretation of nature and establishes that only they can interpret appearances and reveal the true nature of the anatomy of the human body.

The importance of anatomical expertise dates back to well before the eighteenth century. As Silvia de Renzi (2002) has shown, it became especially relevant in the medico-legal activities of the early modern courtrooms.

\footnotetext{
* Palmira Fontes da Costa is Assistant Professor of History of Science at the New University of Lisbon, Portugal. Her research interests include the history of the life sciences from the 16th to the 18th centuries, the history of sexuality, and the history of the book and of visual representations.
}

Spontaneous Generations 1:1 (2007). ISSN 1913-0465. University of Toronto 
Anatomical expertise was also taken into account at the Royal Society of London in the process of assessing the veracity of extraordinary phenomena of nature such as monstrous births. In 1664 Henry Oldenburg, for example, thanked Robert Boyle for sending him a detailed account of a monstrous birth, but requested additionally the "double attestation of two physicians" (Boyle 1965$66,318)$. In this case, Oldenburg considered the circumstantial details of the observation and the fact that it was communicated by a gentleman insufficient for the attestation of the report. Early modern anatomists participated also as crucial experts in the assessment of cases of sanctity, which they could detect through the ascertainment of the extraordinary anatomies of holy bodies (Camporesi 1988).

During the eighteenth century, the role of anatomical expertise became increasingly important and this new trend was particularly evident in the validation of observations of phenomena outside the common course of nature, such as monstrous births (Fontes da Costa 2002). It was also during this period that the increased use and refinement of techniques of dissection contributed to a more important role for anatomical expertise in the authentication of these kind of reports.

I argue in this paper that it is in the realm of interpretation of unusual and ambiguous anatomies that medical and, in particular, anatomical expertise assumed its most crucial role. Moreover, the medical understanding of the hermaphroditic body in the eighteenth century can be considered one of the most illustrative cases of the construction and display of anatomical expertise. In fact, several of the academic memoirs and dissertations published on hermaphrodites in the eighteenth century attempted precisely to fulfil this purpose. ${ }^{1}$

It is true that for the anatomically experienced physician and surgeon, ambiguous sexual appearances were a challenge as well as an opportunity for them to exhibit their anatomical knowledge and skills, and these opportunities could have significant implications for their professional status and credibility. Therefore, several of the memoirs and dissertations on hermaphrodites consisted of meticulous anatomical descriptions of specific case histories associated with sexual ambiguity, often accompanied by visual representations.

\footnotetext{
${ }^{1}$ Several memoirs on hermaphrodites were published by the Mémoires de l'Académie Royale des Sciences de Paris, the Mémoires de l'Académie de Dijon, the journal Observations sur la Physique and the Philosophical Transactions of the Royal Society of London. Eighteenth-Century dissertations on hermaphrodites include James Parsons, A mechanical and critical enquiry into the nature of hermaphrodites (London: J. Waltho, 1741); Albrecht von Haller, "Hermaphroditis? Lecta die 23 aprilis in primo regiae societatis conventu," Commentarii societatis regiae scientiarum Gottingensi, 1 (1752):1-26; Claude Champeaux, Réflexions sur les hermaphrodites, relativement à Anne Gran-Jean, qualifiée telle dans un Mémoire de $M$. Vermeil, avocat au Parlement (Avignon and Lyon: Claude Jacquenod, 1765); and Georges Arnaud de Ronsil, Dissertationsur les hermaphrodites (Paris: Dessain, 1768).
} 
However, the display of anatomical expertise was important in a more fundamental way. Then, as before, establishing the hermaphrodite's anatomical sex was vital since it affected his/her legal and social position. As Lorraine Daston and Katharine Park have shown, in the early modern period "legal and medical authorities worked hand in hand to determine the sex to which the hermaphrodite belonged" $(1995,425)$. In contrast, during the eighteenth century, anatomical expertise was understood more and more to be crucial in deciding the hermaphrodite's predominant sex as well as providing the grounds for such a decision. It was during this period that anatomists asserted their prerogatives over legal authorities, medical practitioners and also midwives in negotiating the sex to which the hermaphrodite belonged.

The main aim of Claude Champeaux's Reflexions on hermaphrodites is to vindicate the authority of anatomists in establishing the sex of Anne Grand-Jean, qualified as hermaphrodite by the lawyer François-Michel Vermeil. In his dissertation, Champeaux displays his ontological expertise by providing a detailed analysis of the genital parts of Gran-Jean and asserts, in opposition to Vermeil, that she is no more than a woman with a big clitoris. Similarly, the memoir "On the true sex of the so called hermaphrodites" by Antoine Ferrein (1770) can be considered illustrative of the claim for the essential role of the anatomist in assessing the sex of human hermaphrodites. From the beginning, the author asserts that he had been consulted by the parents of a young person with doubtful sex to decide her/his "true sex." The decision would have important social and economic implications since it would determine whether the subject under assessment would or would not be heir to a large inheritance. After a brief description of the young person's external features and a detailed examination of his/her "parts of generation," Ferrein declares the hermaphrodite to be in fact a female whose main specificity is the extraordinary size of her clitoris.

If some authors such as Champeaux and Ferrin confined themselves to a painstaking and often intrusive examination of the hermaphrodite's "parts of generation" in order to decide if the subject was an hermaphrodite and, if so, its predominant sex, others attempted to depart from individual cases and to limit the medical understanding of sexual difference by asserting that all of the socalled hermaphrodites were in fact women with deformed genitals. Hence, the main task of the anatomist was no longer to identify the predominant sex of the hermaphrodite but to show how easily the ignorant and superstitious might be deceived by misleading appearances. Only some anatomists had the ontological expertise to decipher the ambiguous sex of some individuals. Prudential expertise could also be important if they had the opportunity to evaluate various subjects described as hermaphrodites but, due to the rarity of these kinds of cases, this possibility was not usually provided to them.

The view that certain of the so-called hermaphrodites were in fact women with deformed genitals had been the argument of a number of seventeenth-century anatomists, most famously Jean Riolan, the younger (1614). 
Yet, for some eighteenth-century anatomists this was true not only for specific occurrences but was a general law of nature. This point of view was tenaciously argued in James Parsons' A mechanical and critical inquiry into the nature of hermaphodites. Parsons' work had been motivated by the exhibition of an "African hermaphrodite" in London throughout 1741. He considered his work to be a kind of "Enlightenment guide" to what should be seen at the public place of the exhibition. What was to be seen was no longer an "African hermaphrodite" but an "Angolan woman." In his work, Parsons displays his anatomical expertise through a meticulous examination of the genital parts. The visual representations presented in the work also had a prominent role in his argumentative strategy to prove that all cases of hermaphrodites were in fact women. In his view, their visual immediacy and explicitness made them his most powerful weapon "to overturn Errors, and undeceive the Crowd that is hurried along through the Mazes and Labyrinths of Misrepresentations" (xv). As Parsons commented in his work, clear and particular anatomical representations were indispensable in giving credit and authenticity to reports of unusual occurrences of nature; only then could they be perceived as true mediators in the perception of nature.

By reducing all hermaphrodites to women with genital deformations, Parsons attempted in this work to erase the concept and the figure of the hermaphrodite altogether from the medical understanding of sexual difference. For Parsons, and others who shared his understanding, only anatomical expertise was able to go beyond appearances and have access to the true order of nature. However, not all British anatomists whose expertise was generally acknowledged by their peers shared the same view on the nature of human hermaphrodites. In fact, the same subject that was categorically classified as no more than a woman by Parsons was described by the famous anatomist William Cheselden as a "wonderful mixture of both sexes" and as "a male" by the eminent surgeon John Freake $(2003,131)$. Physical appearances could, after all, be interpreted in very different ways by anatomists who independently claimed ontological expertise on the subject. In this way, the "African hermaphrodite" defied and problematized the role and authority of the medical profession in mediating sexual difference.

The vision that human hermaphrodites were, after all, just women with genital deformations suited the enlightening purposes of the Encyclopedists well. A first article on hermaphrodites was published in the sixth volume of the French Encyclopédie in 1765 authored by someone lacking anatomical expertise, the polygraph Chevalier de Jaucourt. The article begins by questioning the existence of true hermaphrodites, i.e. of individuals considered to combine the male and female sexes in a distinct and perfect way both in terms of their structure and function. The answer is short and straightforward: "One could debate this issue in times of ignorance; one should no longer address it, 
however, in times of enlightenment. If Nature strays from time to time in its creations, she recoils forever from permitting metamorphoses, confusions of substances and conjoined assemblages of the two sexes" (165). But, should the existence of any kind of hermaphrodite be accepted? De Jaucourt does not give a conclusive answer to this question but suggests that the majority of persons described as hermaphrodites in the popular, legal and medical literature are, in fact, not real hermaphrodites; that, most of them are merely women with genital deformations that can only deceive the credulous and the unlearned (165). By this time, Parsons had become an authority on the subject. Nevertheless, in the last part of the article De Jaucourt accepts, with some disappointment and inevitability, the extreme difficulty in identifying the gender of some persons (167).

Probably indicative of the fact that anatomical expertise became more important in the discussion of the subject and also in an attempt to do more justice to the contemporary interest in hermaphrodites during the eighteenth century, a second article on hermaphrodites appeared in the $12^{\text {th }}$ volume of the Supplement of the French Encyclopédie, published in 1777. This time, the article included various contributions including that of the renowned Albrecht von Haller, and of the physicians Hugues Maret and Philipe-Étienne La Fosse. The second article is indicative of the increasingly relevant role of anatomical expertise in the discussion of the topic but also of the insurmountable obstacles that unusual and ambiguous anomies posed, even for physicians and surgeons competent in anatomical matters.

The first part of the article on hermaphrodites published in the Supplement is by von Haller. This is not his first contribution to the medical understanding of hermaphrodites. His expertise on the subject was first displayed in a dissertation on the subject published in 1752. In this work, von Haller analyses various cases of hermaphroditism in animals and humans and, whenever possible, makes use of anatomical dissections. He admits that most of the so-called human hermaphrodites are in fact men or women with some kind of genital deformations. He considers, nevertheless, that although rare, it is possible to find more extreme cases of sexual ambiguity.

In the same way as De Jeacourt, von Haller begins his contribution to the Encyclopédie on hermaphrodites by framing the subject within the discourse of enlightened rationality: "The centuries of credulity have been numerous; the century of critical endeavour is coming to a close (...) we deny the existence of hermaphrodites" (1777, 359). Just a few lines later, nevertheless, we can see that his declaration is essentially rhetorical and that his views on the subject are less categorical than the first sentence might suggest. When he is referring to the famous case of Marie-Anne Drouart, he admits to major doubts with regard to the identification of her/his sex and suggests that only a proper dissection of the subject will, in the future, be able to decide the issue. On the question of the existence of true hermaphrodites, in accordance with the view he had presented in his previous dissertation on the subject, van Haller does not straightforwardly 
deny their existence (360). He admits only that it would be difficult for such occurrences to exist. He remarks, however, that it seems almost inevitable that one of the two sexes (or both) would be defective and hence that if true hermaphrodites do exist, they can only be imperfect.

The contribution of Juges Maret from the Académie de Dijon and particularly his description of the case of Hubert-Jean-Pierre, who died at the age of 27, adds further uncertainties and difficulties to the understanding of human hermaphrodites. Dissection was a central technique in the deployment of anatomical expertise and was crucial to the privileged access of the anatomist to the hidden structures of the body. However, the ambiguities in the description of Hubert-Jean-Pierre's physical portrait seemed only to be strengthened after the dissection of his/her body:

one could affirm that the subject in question belonged equally both to the female and male sexes, and that Nature had succeeded in conjoining both sexes into one individual. The subsequent dissection of the individual supports this conjecture since it demonstrated that if Jean-Pierre were a female from the waist up and a male from the waist down, he was, essentially, a female on the right side of the body and a male on the left while not being either one or the other (Maret 1777, 361).

Finally, the short contribution to the article by La Fosse (1777) is an attempt to erase altogether the hermaphrodite from eighteenth-century nature and society. Since, for the author, hermaphrodites are only a mythical figure from the past, he considers it no longer meaningful to analyse the subject from the legal point of view. Within this framework, individuals with great ambiguities in the identification of their sex cease to have any rights and they can only be objects of curiosity for physicians, surgeons and the general public.

In conclusion, we may say that the examination and the discussion of the "true" sex of human hermaphrodites in the eighteenth century was often used as an opportunity to exhibit anatomical expertise and to convince others of its importance. In particular, the discussion of the "true sex" of the so-called hermaphrodite shows the crucial importance of ontological expertise in the anatomical literature of the period and also its social relevance for the determination of the legal status of subjects described as hermaphrodites. However, anatomical expertise, even when supported by persuasive visual representations or based on the ultimate analytical arsenal of the anatomist, the dissection tools and the dissection table, was still unable to confine the hermaphrodite's irreducible ambiguity. 


\title{
Acknowledgments
}

I would like to thank José Carlos Pinto for his translation from Latin to Portuguese of Albrecht von Haller's dissertation Hermaphroditis? (1752). I also would like to thank the two anonymous referees of this paper for their very useful comments and suggestions.

\author{
PALMIRA FONTES DA COSTA \\ New University of Lisbon \\ Portugal
}

\section{References}

Boyle, Robert. 1965-1966. The works, ed. Thomas Birch. Hildeschein: G. Olas. Camporesi, Piero. 1988. The incorruptible flesh: Bodily mutilation and mortification in religion and folklore. Cambridge: Cambridge University Press. Champeaux, Claude. 1765. Réflexions sur les hermaphrodites, relativement à Anne Gran-Jean, qualifiée telle dans un Mémoire de M. Vermeil, avocat au Parlement. Avignon and Lyon: Claude Jacquenod.

Daston, Lorraine, and Katherine Park. 1995 . The hermaphrodite and the orders of nature: Sexual ambiguity in early modern France. GLQ: A journal of lesbian \& gay studies. : 419-38.

Ferrein, Antoine. 1770. Mémoire sur le veritable sexe de ceux qu'on appelle hermaphrodites. Mémoires de l'Académie Royal des Sciences, 1330-39.

Fontes da Costa, Palmira. 2002. The making of extraordinary facts: Authentication of singularities of nature at the Royal Society of London in the eighteenth century. Studies in history and philosophy of science 33:265-88.

Fontes da Costa, Palmira. 2003. Mediating sexual difference: The medical understanding of human hermaphrodites in eighteenth-century England. In Cultural approaches to the history of medicine: Mediating medicine in early modern and modern Europe, ed. Willem de Blécourt and Cornelie Usborne, 127-47. Basingstoke: Palgrave Macmillan.

Fosse, Philipe-Étienne La. 1777. Hermaphrodites. In Supplement à l'Encyclopédie, ou Dictionnaire raisonné des sciences, des arts et des métiers, par une Société de Gens de Letrres, ed. André Joseph Panckoucke, Volume IIII, 365. Paris.

Haller, Albrecht von. 1752. Hermaphroditis? Lecta die 23 aprilis in primo regiae societatis conventu. In Commentarii societatis regiae scientiarum Gottingensi. 1:1-26.

Haller, Albrecht von. 1777. Hermaphrodites. In Supplement à l'Encyclopédie, ou Dictionnaire raisonné des sciences, des arts et des métiers, par une Société de Gens de Letrres, ed. André Joseph Panckoucke, Volume IIII, 359-360. Paris.

Jaucourt, Chevalier de. 1765. Hermaphrodites. In Encyclopédie, ou Dictionnaire raisonné des sciences, des arts et des métiers, par une Société de Gens de Letrres, eds. Diderot and d'Alembert, Volume VI, 165-7. Genéve. 
Maret, Hugues. 1777. Hermaphrodites. In Supplement à l'Encyclopédie, ou Dictionnaire raisonné des sciences, des arts et des métiers, par une Société de Gens de Letrres, ed. André Joseph Panckoucke, Volume IIII, 360-2. Paris.

Morand, Sauveur-François. 1754. Description d'un hermaphrodite, que I'on voyait à Paris. In Mémoires de l'Académie Royal des Sciences. 109-12.

Parsons, James. 1741. A Mechanical and critical enquiry into the nature of hermaphrodites. London: J. Waltho.

Renzi, Silvia de. 2002. Witnesses of the body. Medico-legal cases in seventeenthcentury Rome. Studies in History and Philosophy of Science, 33: 219-42.

Riolan, Jean. 1614. Discours sur les hermaphrodites. Paris: Pierre Ramier.

Ronsil, Georges Arnaud de. 1768. Dissertationsur les hermaphrodites. Paris: Dessain.

Shapin, Steven. 1995. A social history of truth: Civility and science in seventeenthcentury England. Chicago: Chicago University Press.

Shapin, Steven. 2003. Trusting George Cheyne: Scientific expertise, common sense, and moral authority in early eighteenth-century dietetic medicine. Bulletin of the history of medicine 77: 263-97. 